\title{
Are Organic Food Labels Inadequate? Evidence from Consumers in Australia
}

\author{
Joanna Henryks ${ }^{1}$, David Pearson ${ }^{2}$, Tatiana Anisimova ${ }^{1}$, Parves Sultan ${ }^{3}$ \\ ${ }^{1}$ Assistant Professor, Faculty of Arts and Design, University of Canberra, Australia \\ ${ }^{2}$ Professor, Faculty of Arts and Design, University of Canberra, Australia \\ ${ }^{3}$ Senior Lecturer, School of Business and Law, Central Queensland University, Australia \\ Correspondence: Joanna Henryks, Faculty of Arts and Design, University of Canberra, ACT, 2600, Australia
}

Received: May 1, 2015 Accepted: May 13, 2015 Online Published: May 28, 2015

doi:10.11114/bms.v1i2.808 URL: http://dx.doi.org/10.11114/bms.v1i2.808

\begin{abstract}
The organic sector is one of the fastest growing food markets in the developed world, with a significant number of consumers continuing to prioritise these products that are perceived to be healthier and more sustainably sourced. The body of existing research has identified that very few consumers are dedicated organic food buyers hence most are purchasing it only some of the time. The most commonly identified barriers to purchasing more are associated with price premiums and limited availability. This paper adds to the literature by exploring another barrier, that of potentially inadequate information on product labels. Based on a large study of consumers in Australia $(\mathrm{N}=1011)$ findings show the majority feel information provided on labels is inadequate, and that this has a negative impact on their purchasing behaviour. Priorities for the organic industry to address this consumer concern are enhancing visibility and confidence in organic certification logos, and explaining what organic food is on product labels. Enhancing these marketing communications by providing supporting information via the Internet, as it is now more important than product labels, is likely to further enhance sales.
\end{abstract}

Keywords: organic food movement, buyer behaviour, communication, information, certification, brand

\section{Introduction}

Organic food is grown and sold throughout the world but contributes only a small amount of total global food supply. While potential for significant growth remains, this will only be achieved with enduring expansion of all stages along the food supply chain - from growing through to transport, processing and ultimately retailing. All organisations who contribute to the supply of organic food are important, however this article focuses on consumers, who, collectively, are responsible for creation of the ultimate source of demand. Whilst research has contributed to understanding those who purchase organic food, much remains to be learnt. This paper adds to the existing body of knowledge by presenting empirical results in relation to information that is available (or not) to consumers who purchase organic food.

\subsection{Literature Review}

Consumer interest in organic food is reflected in global sales of USD 63 billion with consistent annual increases (Willer, Lernoud \& Kilcher, 2013). However, although organic food sales continue to expand, they still account for a small percentage of the overall food market (Aertsens, Verbeke, Mondelaers \& Huylenbroect, 2009). For example market share statistics from around the developed world show Denmark (the largest share in the world) $7.6 \%$ (Danish Agriculture \& Food Council [DAFC], 2014), Germany 3.5\% (Willer et al., 2013), around 4\% in the United States (Organic Traders Association [OTA], 2011), whilst in Australia it is estimated to be around only 1\% (Biological Farmers of Australia [BFA], 2012). Most adults in these countries purchase organic food: for example $80 \%$ in UK (Soil Association [SA], 2013), 81\% in USA (Organic Traders Association [OTA] 2013) and 65\% in Australia (BFA, 2012). Organic food is the dominant food choice for an extremely small group as most only purchase it some of the time (Lockie, Lyons, Lawrence \& Grice, 2004; Pearson, Henryks \& Jones, 2011). This explains why market share is much lower than the percentage of consumers who purchase organic food. Understanding consumer motivations and buying behaviour is critical to facilitating market growth. 
The reasons many consumers choose to purchase organic food are primarily based around what it does not include rather than what it does (BFA, 2012). The absence of genetically modified organisms, pesticides, fungicides, artificial fertilizers and insecticides results in a product that is perceived to be 'free from' unhealthy additives. Hence organic food is perceived to be healthier (Hughner, McDonagh, Prothero, Shultz \& Stanton, 2007; Pearson \& Henryks, 2008; Shepherd, Magnusson \& Sjödén, 2005). Research also shows that some consumers of some organic products perceive them to be tastier (Fearne, 2008; Lea \& Worsley 2005; Lyons, Lockie \& Lawrence, 2001) although this research has not been substantiated in blind taste tests (Fillion \& Arazi, 2002). Another reason why some people consume organic food is that it is perceived to be better for the environment (Aertsens et al., 2009; Bauer, Heinrich \& Schäfer, 2013; Padilla, Cordts, Schulze \& Spiller, 2013; Thøgersen, 2010). Although these beliefs positively predispose consumers to purchase organic food, barriers also exist. The most frequently cited barriers to organic food purchases are price, availability and appearance. Each of these will be explored briefly in turn.

It is not surprising that price is an often cited barrier (Lockie, Lyons, Lawrence \& Mummery, 2002; McEachern \& Willock, 2004; Shepherd et al., 2005) as organic food carries a price premium when compared with its conventional counterpart. Despite this premium, it is possible that price is reported as a barrier because it is an easy explanation for why consumers do not buy organic food. Some research has uncovered evidence suggesting that to conclude price is a barrier may be simplistic. Consumers, despite complaining about price, are either unclear, unable to specify what it actually is or simply incorrect when it comes to reporting price paid for individual food products (Lampkin, 2002).

Similarly, research into supermarket shopping has also found that 'a sizeable percentage of consumers buy products without knowing their price... (which) does not necessarily imply that consumers do not care about price' (Grunert, 2007). In exploring some of the evidence, we would suggest that there may be other factors that also come into play. For example, the average Australian spends just over \$A20 per week on fresh fruit and vegetables and over \$A80 on alcohol, soft drinks, takeaway food and confectionary (Australian Bureau of Statistics [ABS], 2011). In the United Kingdom, weekly food and drink expenditure is 51 EUR (\$A72) per person per week and the average household, 24\% of weekly food expenditure goes to fruit and vegetables, $22 \%$ to foods classified as high in fat and/or sugar (Department for Environment, Food \& Rural Affairs [DEFRA], 2013). Finally, in the USA, nearly half of food spend is on food outside the home (Martinez \& Kaufman, 2008). This suggests that it is not just an affordability issue but possibly one of priorities for some consumers. In addition, studies have found that lower income is not a barrier to purchasing organic food (Goldman \& Clancy, 1991; Jolly, Schutz, Diaz-Knauf \& Johal, 1989; Newspoll 2008).

Availability is another commonly cited barrier to the purchase of organic food (Buder, Feldmann \& Hamm, 2014, Hoppe, Vieira \& Barcellos, 2013, McEachern \& Willock, 2004; Shepherd et al., 2005). Whereas once organic food tended to be found in specialty stores such as health food and food co-operatives, it is now available throughout major retail food outlets in the developed world. However, consumers still mention it as a barrier. If, for example, a consumer's food of choice is not available in their regular retail outlet, it can become inconvenient to source it at another retail outlet. This is likely to lead to lower purchasing frequency with consumers choosing to substitute organic food with conventional. Research has also shown that some consumers do not always notice, at the point of purchase, that food is labelled organic (Henryks, Cooksey \& Wright, 2014). The aforementioned study also found that consumers occasionally purchased organic when they thought it to be conventional and vice versa thus potentially leading to incorrect self-reporting of organic food purchases.

Appearance is another barrier to purchase cited by some consumers (Fearne, 2008; Thompson \& Kidwell, 1998). Due to the lack of pesticides and insecticides used in the production some organic fresh fruit and vegetables may have blemishes or not be of perfect shape. Fresh food produced by conventional agricultural systems tends to lack such imperfections and be uniform in size, shape and colour. Interestingly and conversely, some consumers view pest markings as a sign that the food is organic (Henryks \& Pearson, 2010). With the increasing industrialization of the organic food chain, mainstream organic produce is starting to resemble its conventional counterpart and consequently this may become less of an issue in the future. Understanding these consumer beliefs and barriers helps provide an understanding for the reasons consumers may or may not buy organic food. However, it does not fully explain its relatively low market share. Other studies suggest that a lack of information about organic food is acting as a barrier to consumers purchasing more of it (Harper \& Makatouni, 2002; Yin, Wu, Du \& Chen, 2010). Hence, additional marketing communications aiming to popularise organic foods amongst various consumer groups may be important to increasing sales and market share (Hughner et al 2007, Pearson, Henryks \& Moffitt, 2007; Latacz-Lohmann \& Foster, 1997).

Information about organic food can be communicated through many avenues including advertising, advertorials, and point of purchase communications. From a marketing perspective, product labelling is a vital source of information at point of purchase and is within control of organisations in the supply chain. However, designing labels is challenging: consumers can be either overwhelmed by too much information or be misled by too little (Wansink, 2003). Further, 
consumers may make assumptions about the product based on the imagery or logos which are not always accurate (Conner \& Christy, 2004; Hoogland, de Boer \& Boersema, 2007; Janssen \& Hamm, 2012). For example, consumers may consider pictures of green hills on raw chicken packaging to signal the product is organic when it is free range (Henryks \& Pearson, 2010). Research also shows many consumers, even when they do take the time to look at on pack information, only do it briefly (Higginson, 2002). If this is the case, it becomes important to consider how consumers actually perceive the messages. As Hoogland et al. (2007) state: 'just because consumers do not pay attention to the label most of the time, those scarce moments when they actually do read it can be extremely important'.

Appropriate information on product labels may assist in increasing sales of organic food. Janssen, Heid \& Hamm (2009) suggest that new consumers are more likely to purchase organic products when they see additional product information (such as information on labelling) on the benefits of the organic production system. Similarly, Smed \& Andersen (2012) found that once consumers are purchasing organic vegetables, information about the health benefits can increase purchases. A third area of research pertains to organic certification, where some consumers lack knowledge on what it is (Hoogland et al., 2007; Sawyer, Kerr \& Hobbs, 2008). These studies suggest that more information may help increase sales and one avenue for providing this is through product labels.

\subsection{Aim}

In this paper we explore consumer perceptions of organic food labelling in Australia in order to gain further understanding into whether this is an area that provides an opportunity for improved communication. In Australia there are seven independent certification organisations and additional ones for imported products, with their own logos placed on products to indicate its certified organic status. Thus consumers see different certification brands on different organic products. This is in contrast to one consistent brand on all certified organic products, which has been the case in USA for some time and has recently been implemented in the European Union (Organic Federation of Australia [OFA], 2014). Thus, the research question explored in this paper is Do organic food consumers in Australia perceive organic food labelling as clear and, if not, where are the gaps in clarity?

The aim of this research is to provide an understanding of consumers' current perceptions of organic food labelling. This will provide organic food marketers with a baseline of understanding of consumer knowledge as well as a perspective on the effectiveness of their existing marketing communications and importantly opportunities for improvements.

\section{Method}

\subsection{The Research Instrument}

This paper reports the findings from one section of a larger online questionnaire for consumers in Australia investigating the role of marketing communications. A structured questionnaire was developed by and pilot tested to determine appropriateness of wording and length of time taken to complete. The questionnaire was standardized and undisguised for respondents.

\subsection{The Pilot Study}

Using a sample of 37 subjects, a pilot study was undertaken by a research agency who also recruited respondents and collected the data. The responses were obtained and analysed. Several minor adjustments were made. In order to decrease response fatigue (Burchell \& Marsh, 1992), the length of the questionnaire was decreased and the wording in several questions was changed to achieve greater clarity.

\subsection{The Survey}

Data were collected during November 2012 via an online survey undertaken by the Australian subsidiary of a global market research consultancy. Respondents were randomly recruited from a national research panel. The only prerequisite for qualifying for this project was that respondents had to have purchased organic products sometime in the past. The online survey method was considered the most appropriate for the data collection due to it being able to access unique populations, an ability to accommodate large sample sizes at relatively low costs, and in a short amount of time (Wright, 2005).

A total of 1011 usable questionnaires were obtained. The response rate was 5.74\%. This relatively low rate is common with web-based surveys (Sax, Gilmartin \& Bryant, 2003). An additional 508 questionnaires were returned incomplete and 311 respondents were screened out as these respondents had not purchased organic food (That is by selecting 'Never' in response to 'Please indicate how often you purchase organic food products').

Apart from the purchasing frequency construct that was measured using a four-point scale, all the study constructs were measured using a seven-point Likert scale. Likert scales are recommended for empirical studies that measure marketing and brands (Anisimova \& Thomson, 2012). To minimize the potential issues with validity of the data, the neutral 
response alternative was included. The number (4) 'neither agree nor disagree' provided a neutral response. The survey finished with a section on demographics.

'Open ended' questions were also utilized to obtain additional insights. These are a useful method in consumer research that enables respondents to describe issues of importance in their own words (Ares, Gimenez, Barreiro \& Gambaro, 2010). Another appeal of the data from open ended questions is that it can provide a relatively rich description of respondents' views of issues under investigation at a relatively low cost and can offer greater anonymity to respondents than other qualitative techniques thereby eliciting more genuine responses. Samples of the actual responses are also included to illustrate the vocabulary used by respondents.

\section{Results and Discussion}

Following presentation of demographic profile of questionnaire respondents empirical results are discussed in four subsections: Where consumers find information about organic foods, Clarity of organic food labels, Lack of clarity of information and impact on purchase behaviour, and finally, Factors contributing to lack of clarity on organic food labels. Results are presented in the form of descriptive statistics followed by discussion of trends, if any, that are evident from further analysis using cross tabulations by age group and purchase frequency. Descriptors for the age group categories are: young adult (18-29 years), parent (30-44) empty nester (45-64), and finally, retiree (65+). Descriptors for the four categories of purchase frequency are: used to (but no longer purchase organic food), rarely (1-3 times per month); often (at least 1-3 times per fortnight), and regularly (at least 1-3 times per week).

The demographic profile of questionnaire respondents is as follows. Gender female (50.5\%); age young adult (17\%), parent (35\%), empty nester (32\%), and finally, retiree (16\%); location large city $70 \%$; household income $<\$ 45,000$ $(25 \%), \$ 45,000$ to $\$ 105,000(43 \%),>\$ 105,000(17 \%)$, and Prefer not to say (15\%). In relation to frequency of organic food purchases; used to (9\%), rarely (45\%), often (30\%), and regularly (16\%).

\subsection{Where Do Consumers Find Information about Organic Foods?}

In order to explore this area, answers to an open ended question: Please tell us how you source information about organic food were collected. Multiple responses were permitted. The results have been collated in the following (Figure 1).

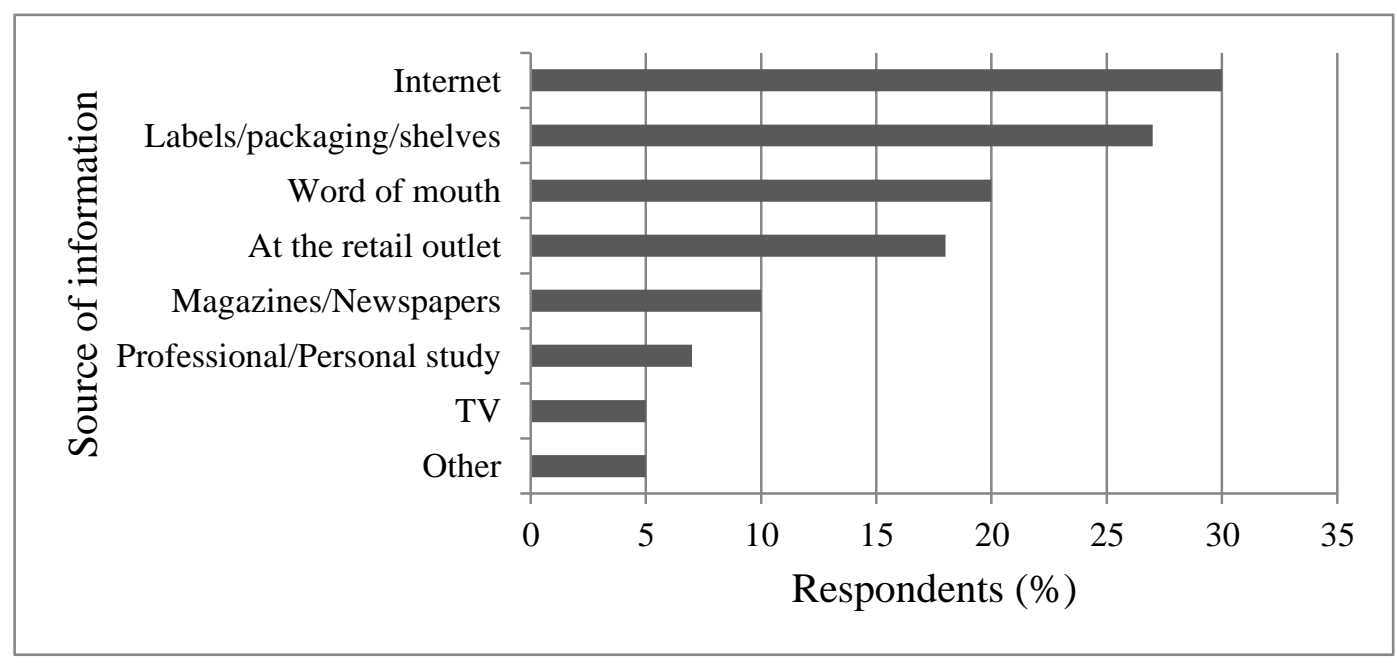

Figure 1. Sources of information used by consumers who purchase organic food $(\mathrm{n}=957)$.

The Internet (30\%) is cited most often as the source where respondents obtain information about organic food. Packaging, labels and shelves at the point of purchase are the second most cited source (27\%). Word of mouth (20\%) and at retail outlet (18\%) itself are mentioned by around one in five respondents and smaller numbers of respondents cited magazines and newspapers (10\%), professional interest or personal study (7\%) and television (5\%). Numerous other sources were grouped under 'other' category and included brochures, catalogues, radio, promotions, samples, email, and newsletters (5\%).

Further analysis of this data demonstrates a higher use of the Internet in the younger groups than the older groups. For example, almost half (44\%) of young adults (18-29 age group) use Internet in comparison to only one in five (18\%) retirees (65+ age group). Interestingly younger groups are less likely to use information provided at point of purchase, such as young adults (18\%) versus retirees $(30 \%)$. 
Finally word of mouth is also more popular with younger groups, such as young adults (27\%) versus retirees (20\%). Although of relatively low importance overall (at less than 10\%) personal study and traditional media (such as magazines and newspapers) increase in importance for older age groups.

Previously published results, analysing purchase frequency from the same online questionnaire for consumers in Australia, identified that there is a general trend towards younger consumers purchasing organic food more frequently (Pearson, Henryks, Sultan \& Anisimova, 2013). Hence, those more likely to purchase organic food tend to be younger and source information to a greater extent from the Internet and word of mouth, rather than from product labels. The key conclusion from this analysis is recognition of the dominant role played by the Internet as the most important source of information for consumers. However, further research would be required to identify which Internet sources are being used by consumers, and these are likely to include those sponsored by industry, government, and not for profit organisations and individuals.

This paper continues by further investigating the second most important source of information for consumers. Product labels provide information to consumers at the point of purchase and the information provided on labels is almost entirely industry-controlled.

\subsection{Clarity of Organic Food Labels}

In order to explore this area respondents were asked How clear is the information on organic food labels to you? on a seven point Likert scale, from completely unclear through to completely clear. To assist the presentation these results have been aggregrated into three groups, clear, neutral, and unclear. These are presented in the following (Figure 2).

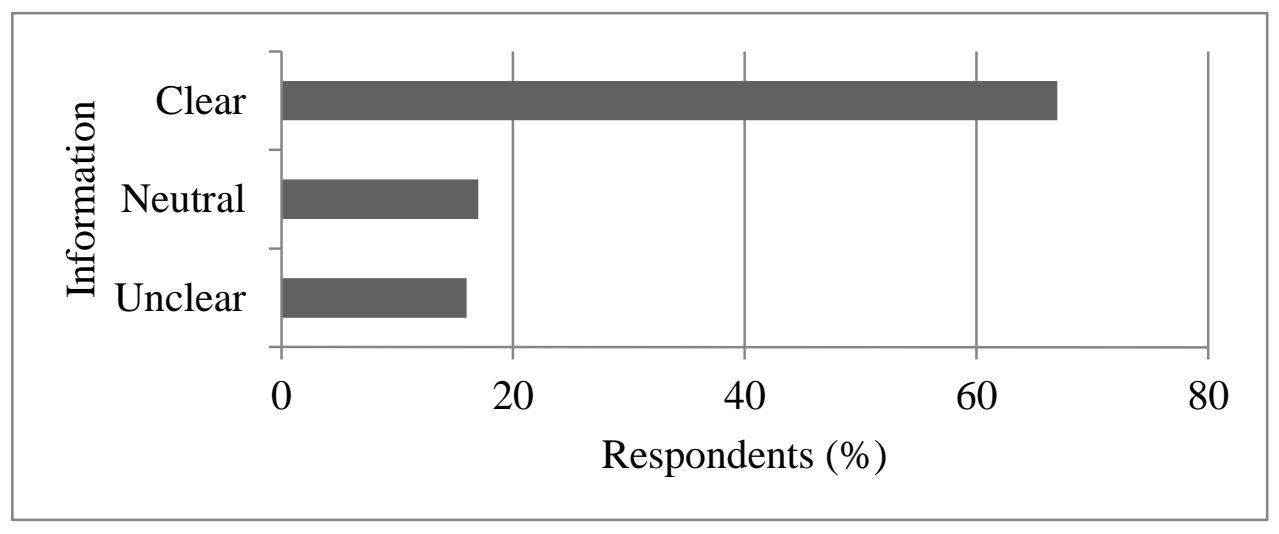

Figure 2. Clarity of information on organic food labels $(\mathrm{n}=1011)$

The majority (67\%) of respondents feel that the information provided on organic food labels is clear and only a few $(16 \%)$ feel that it is unclear. Further analysis of this data shows that the more often a consumer purchases organic food the clearer they perceive the labels to be. For example, most (81\%) of regular buyers, compared to just over half (60\%) who purchase rarely, feel that the labels are clear. There are no trends evident from perspective of respondents' age.

One plausible conclusion from this analysis is that organic consumers generally found labelling clear, and that the greatest clarity was found amongst regular users of organic food. This suggests committed buyers, not surprisingly, have a greater understanding of organic processes and so labelling presents less new or challenging information to them. They are therefore more confident they understand information provided on labels.

However, this conclusion obscures a very important observation about the lack of clarity on organic food labels. Based on the information provided in Figure 2, a minority (16\%) found there to be a lack of clarity, whilst analysis of the data aggregated to create this Figure show that organic food labels are 'completely clear' to only a very small number (3\%), hence almost all respondents (97\%) felt that there were some areas in which the labelling could be improved. As one open text comment from a respondent stated 'If the information is vague, I'd rather choose another product that will show me concrete information...' What is unclear, and how this impacts on purchase decisions, are discussed in the following sections.

\subsection{Lack of Clarity of Information and Impact on Purchase Behaviour}

In order to explore this area respondents were asked Does a lack of information or confusing information affect your purchases of organic foods? on a seven point scale, from Not at All through to A Very Great Extent. These results are presented in the following (Figure 3). 


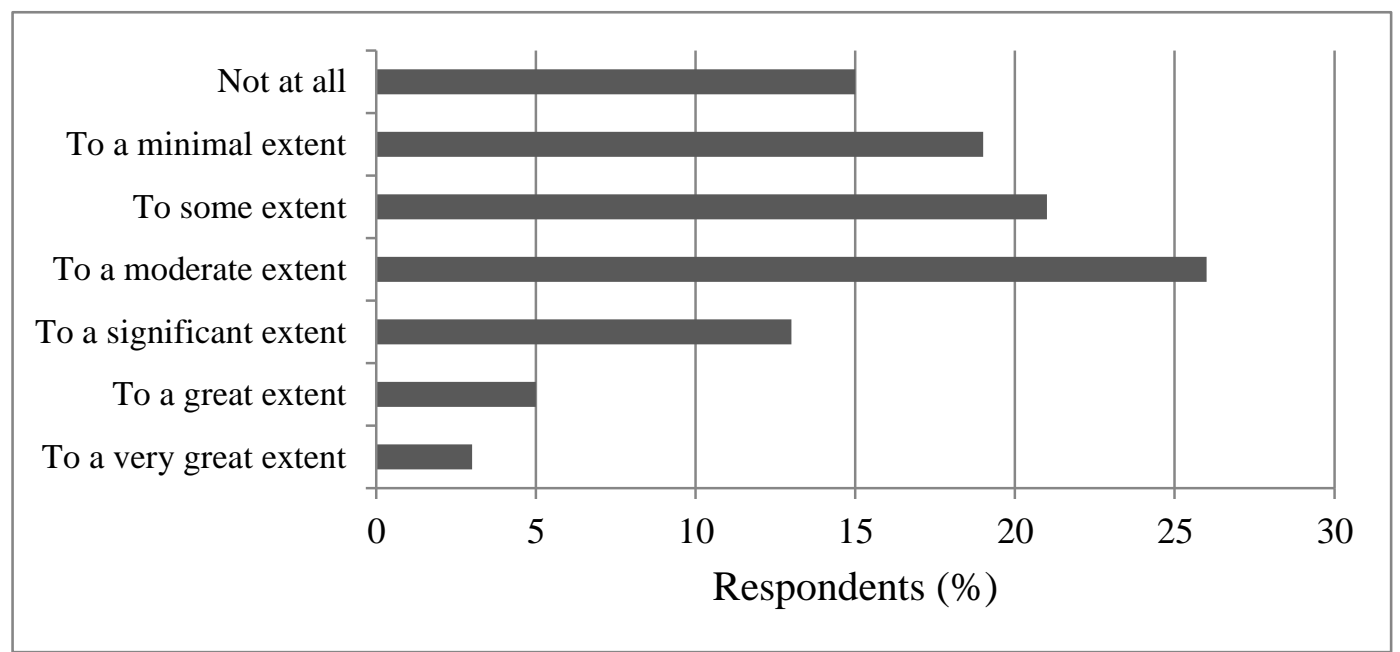

Figure 3. Lack of clarity of information and impact on purchase behaviour $(\mathrm{n}=1011)$

The vast majority (85\%) of respondents felt that the lack of clarity of information provided on organic food labels had some impact on their purchase behaviour. It would seem reasonable to assume that the difference between almost all (97\%) who felt there were some areas in which labelling could be improved, as previously discussed, and this vast majority (85\%) is accounted for by respondents who continued to purchase whilst still feeling that there was lack of clarity. There were no trends evident from further analysis of this data from the perspective of respondent's age or purchase frequency.

\subsection{Factors Contributing to Lack of Clarity on Organic Food Labels}

In order to gain further insight into what people found confusing in relation to orgnaic food labelling, answers to an open ended question was asked: What, if anything, do you find confusing or unclear on organic food labels? were collected. The results have been collated in the following (Figure 4).

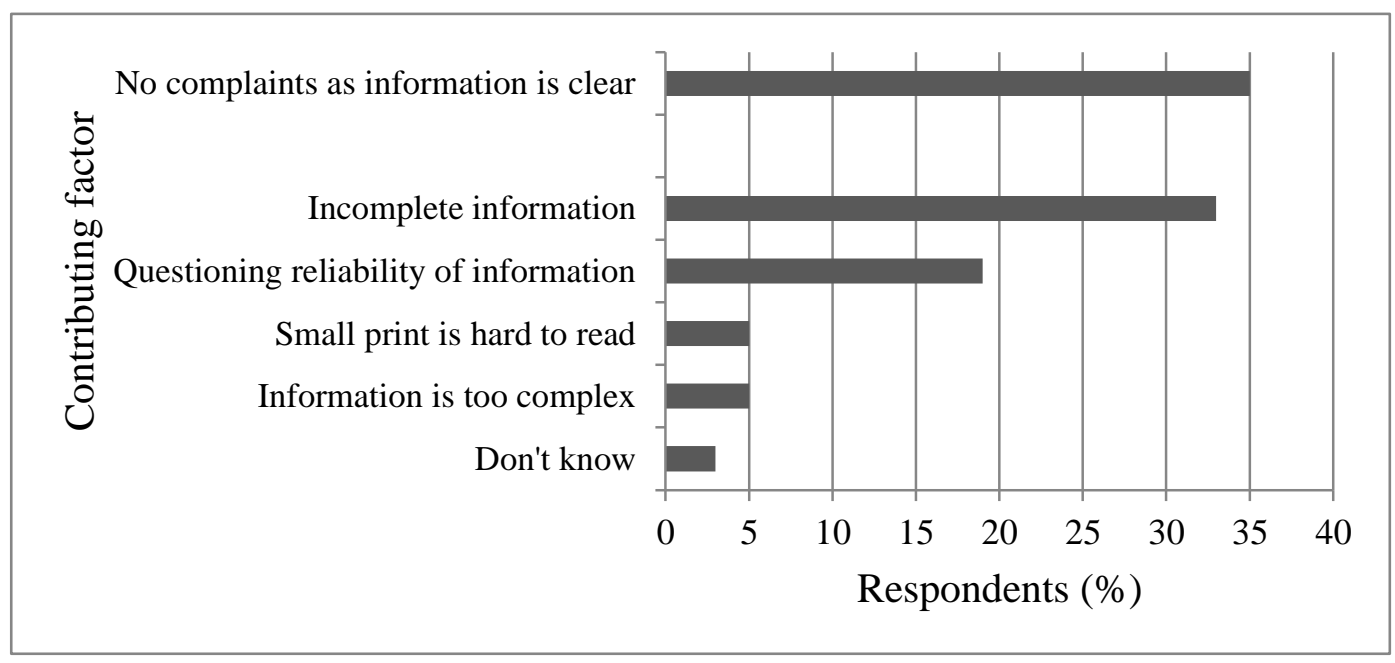

Figure 4. Factors contributing to lack of clarity on organic food labels $(n=828)$

A large number of respondents, one in three (35\%), felt that information provided on organic food labels was clear. It is difficult to reconcile this number with the very small number (3\%) who felt that organic food labels where 'completely clear' as previously discussed. However, suffice to assume that the minority (in the range 3-35\%) are satisfied with information provided on organic food labels.

Of the majority (65\%) from Figure 4 who are not satisfied with information provided, a large number (33\%) felt that the information was incomplete with the four areas of concern being not enough information (15\%), insufficient information on where ingredients come from (9\%), no definition of organic $(7 \%)$ and benefits of organic not clear $(2 \%)$. Providing more information about what organic food is would appear to be an important factor in meeting consumer expectations and encouraging more purchases.

Respondents also expressed concern about the reliability of information provided on the label (19\%), with some 
uncertainty as to whether products were truly organic. One open text comment from a respondent stated 'If I don't know if it's completely organic I might as well buy a cheaper non-organic product.'

With the less important areas being that information was too complex (5\%) or hard to read due to small font size (5\%), the latter being being more of an issue for older age groups. There were no other trends evident from further analysis of this data from the perspective of respondents' age. However, respondent satisfaction with labelling increased with frequency of purchase. Again this suggests committed buyers, not surprisingly, are the most confident in terms of available information on organic labels.

\subsection{Managerial Implications}

The aim of this research is to provide an understanding of consumers' current perceptions of organic food labelling in Australia. This research provides organic food marketers with a baseline of understanding of consumer perceptions as well as a perspective on the effectiveness of their existing marketing communications and importantly opportunities for improvements. Key findings include the importance of word of mouth, the role of labelling and use of the Internet to source information.

Firstly, as in many areas of food marketing, the Internet is becoming an ever increasing source of information for consumers. People readily 'google' and use the Internet as a information bible without necessarily verifying the quality of the information. To this end, it is critical that organic organisations and their Industry bodies regularly 'google' search terms related to their products, or the term 'Certified Organic', in order to be aware of how their products, and organic food in general is being viewed. This also provides an opportunity to engage in public discourse online and ensure correct and adequate information is available to consumers.

Secondly, product labels are an important source of information for consumers, and importantly, an area where organic industry producers have almost complete control of information. Product labeling is also an important consideration with Australia's aging population. Eyesight often declines with age and consequently, it is important to ensure that organic product labeling is visible and clear to those with reduced vision. Organic products with labels that are easier to read for vision reduced consumers may have a competitve advantage at the point of purchase. Any potential changes to product labeling should be tested with vision reduced consumers as well as those with healthy vision.

In addition the research identified that meeting some consumer expectations around labeling information will require providing more information about organic food. This can be a challenge to pack designers, as space on labels is limited. QR codes (abbreviated from Quick Response and seen by consumers as a two-dimensional barcode) can be useful conveying more information on organic food labels. QR codes minimize the use of on-pack space whilst providing interested consumers with a way of obtaining further information. Consumers can take a photo of the QR code on their mobile phone, which will direct them to a website.

Finally, enhancing consumer trust in the label through evidence of organic certification, is also important to increasing consumer confidence and potentially sales. Clearer certification status in labeling, may go some way to building trust in organic products.

\section{Conclusion}

The majority of organic food buyers are not satisfied with the labelling of these products and this has a negative impact on their purchasing behaviour. This suggests improving information provided on product labels could erode a barrier to consumer purchases, and hence contribute to increasing sales. The most important conclusion from the results presented in this paper is recognition of the dominant role played by the Internet as the most important source of information on organic food. Further younger consumers, who also tend to buy more organic food, rely to a greater degree on information from the Internet and more on word of mouth rather than from product labels.

Labelling may play a key role in consumer information seeking behaviour and their decision-making at the point of purchase. This paper has identified areas in which the organic industry is able to improve the labelling of its products. In all situations it is important to ensure that information on labels is accessible, clear and relevant. As one respondent in an open text comment stated 'I want a quick and simple message, these messages decide whether or not I analyse the whole product before purchasing'.

\subsection{Limitations and Future Research}

This research was undertaken at the general level. Hence it is likely that within the organic industry there are product labels that fully satisfy consumer's information seeking requirements and these could be used as exemplars. Further research that includes specific examples of labels would be required to identify these.

This research grouped all information on the product packaging into the concept of a label. However, there are many different components of this information that are controlled by different organisations, and these may have different 
purposes. A salient example is the difference between the manufacturers label and say the label provided by the organisation that provided certification of the product being organic. Again further research in this area would be likely to provide valuable insights.

Finally, given that the Internet is the most popular source of information, particularly amongst younger consumers, further research would be required to identify which websites are being accessed. Identification of those sponsored by industry, government, not for profit organisations, and individuals would provide valuable knowledge for where the organisations in the organic industry would benefit from making their information available. However, caution should be exercised as the causal connection along the path of questionnaire respondents asking for more information, actually taking notice of it, and then changing their behaviour is fragile. Hence more information may not increase sales.

\section{Acknowledgments}

An earlier version of the empirical information presented in this paper was published Henryks, J. Pearson, D. Sultan, P. \& Anisimova, T. (2013) The Labelling of Organic Food: Understanding consumer perceptions. International Food Marketing Conference, Institute of Food Products Marketing, Budapest, Hungary, June 20-21, Part 2, 20-42.

The research supporting this paper was funded by University of Canberra, Organic Federation of Australia, and National Association of Sustainable Agriculture Australia.

\section{References}

Aertsens, J., Verbeke, W., Mondelaers, K., \& Huylenbroect, G. V. (2009). Personal determinants of organic food consumption: a review. British Food Journal, 111(10), 1140-1167. http://dx.doi.org/10.1108/00070700910992961

Anisimova, T., \& Thomson, S., (2012). Using multi-method research methodologies for more informed decision making. Journal of Administration \& Governance, 7(1), 96-104.

Ares, G., Gimenez, A., Barreiro, C., \& Gambaro, A. (2010). Use of an open-ended question to identify drivers of liking of milk desserts. Comparison with preference mapping techniques, Food Quality and Preference. 21(3), 286-294. http://dx.doi.org/10.1016/j.foodqual.2009.05.006

Australian Bureau of Statistics, (2011). Household expenditure survey. Catalogue Number 6530.0 Canberra, Australian Bureau of Statistics.

Bauer, H., Heinrich, D., \& Schäfer, D. (2013). The effects of organic labels on global, local, and private brands: More hype than substance? Journal of Business Research, 66(8), 1035-1043. http://dx.doi.org/10.1016/j.jbusres.2011.12.028

Biological Farmers of Australia. (2012). Australian Organic Market Report. Brisbane, Australia, Biological Farmers of Australia.

Buder, F., Feldmann, C., \& Hamm, U. (2014). Why regular buyers of organic food still buy many conventional products - Product-specific purchase barriers for organic food consumers. British Food Journal, 116(3), 390-404. http://dx.doi.org/10.1108/BFJ-04-2012-0087

Burchell, B., \& Marsh, C. (1992). The effect of questionnaire length on survey response. Quality and Quantity, 26, 233-244. http://dx.doi.org/10.1007/BF00172427

Conner, D., \& Christy, R. (2004). The organic label: how to reconcile its meaning with consumer preferences. Journal of Food Distribution Research, 35(1), 40-43.

Danish Agriculture \& Food Council. (2014). Organic Farming. Danish Agriculture \& Food Council. http://www.agricultureandfood.dk/Danish_Agriculture_and_Food/Organic_farming.aspx (retrieved 21 May 2014).

Department for Environment, Food \& Rural Affairs. (2013). Family Food 2012. Department for Environment, Food and Rural Affairs. London, UK. https://www.gov.uk/government/publications/family-food-2012

Fearne, A. (2008). Organic fruit and vegetables - who buys what and why... and do we have a clue? University of Kent, Canterbury: Dunnhumby Academy of Consumer Research.

Fillion, L., \& Arazi, S. (2002). Does organic food taste better? A claim substantiation approach. Nutrition \& Food Science, 32(4), 153-157. http://dx.doi.org/10.1108/00346650210436262

Goldman, B., \& Clancy, K. (1991). A survey of organic produce purchases and related attitudes of food cooperative shoppers. American Journal of Alternative Agriculture, 6(2), 89-96. http://dx.doi.org/10.1017/S0889189300003933

Grunert, K. (2007). Marketing parameters and their influence on consumer food choice. Shepherd, R., Raats, M., (eds), The Psychology of Food Choice. Oxfordshire, UK: CABI. 161- 177. 
Harper, G., \& Makatouni, A. (2002). Consumer perception of organic food production and farm animal welfare. British Food Journal, 104(3-5), 287-299. http://dx.doi.org/10.1108/00070700210425723

Henryks, J., \& Pearson, D. (2010). Misreading between the lines: Consumer confusion over organic food labelling. Australian Journal of Communication, 37(3), 73-86.

Henryks, J., Cooksey, R., \& Wright, V. (2014). Organic Food at the Point of Purchase: Understanding inconsistency in consumer choice patterns. Journal of Food Products Marketing, 20(5), 452-475. http://dx.doi.org/10.1080/10454446.2013.838529

Higginson, C., Kirk, T., Rayner, M., \& Draper, S. (2002). How do consumers use nutrition label information? Nutrition \& Food Science, 32(4), 145-152. http://dx.doi.org/10.1108/00346650210436253

Hoogland, C., de Boer, J., \& Boersema, J. (2007). Food and sustainability: Do consumers recognize, understand and value on-package information on production standards? Appetite, 49(1), 47-57. http://dx.doi.org/10.1016/j.appet.2006.11.009

Hoppe, A., Vieira, L., \& Barcellos, M. (2013). Consumer behaviour towards organic food in porto alegre: an application of the theory of planned behaviour. Revista de Economia e Sociologia Rural, 51(1), 69-90. http://dx.doi.org/10.1590/S0103-20032013000100004

Hughner, R. S., McDonagh, P., Prothero, A., Shultz, C. J., \& Stanton, J. (2007). Who are organic food consumers? A compilation and review of why people purchase organic food. Journal of Consumer Behaviour, 6(2-3), 94-110. http://dx.doi.org/10.1002/cb.210

Janssen, M., \& Hamm, U. (2012). Product labelling in the market for organic food: Consumer preferences and willingness-to-pay for different organic certification logos. Food Quality and Preference, 25(1), 9-22. http://dx.doi.org/10.1016/j.foodqual.2011.12.004

Janssen, M., Heid, A., \& Hamm, U. (2009). Is there a promising market 'in between' organic and conventional food? Analysis of consumer preferences. Renewable Agriculture and Food Systems, 24(3), 205-213. http://dx.doi.org/10.1017/S1742170509990056

Jolly, D., Schutz, H., Diaz-Knauf, K., \& Johal, J. (1989). Organic foods: Consumer attitudes and use. Food Technology, 43(11), 60-66.

Lampkin, N. (2002). Organic Farming. Ipswich, Australia: Old Pond.

Latacz-Lohmann, U., \& Foster, C. (1997). From "niche" to "mainstream"-strategies for marketing organic food in Germany and the UK. British Food Journal, 99(8), 275-283. http://dx.doi.org/10.1108/00070709710188336

Lea, E., \& Worsley, T. (2005). Australians' organic food beliefs, demographics and values. British Food Journal, 107(11), 855-859. http://dx.doi.org/10.1108/00070700510629797

Lockie, S., Lyons, K., Lawrence, G., \& Grice, J. (2004). Choosing organics: a path analysis of factors underlying the selection of organic food among Australian consumers. Appetite, 43(2), 135-146. http://dx.doi.org/10.1016/j.appet.2004.02.004

Lockie, S., Lyons, K., Lawrence, G., \& Mummery, K. (2002). Eating green: Motivations behind organic food consumption in Australia. Socialogia Ruralis, 42(1), 20-37. http://dx.doi.org/10.1111/1467-9523.00200

Lyons, K., Lockie, S., \& Lawrence, G.(2001). Consuming "green": The symbolic construction of organic foods. Rural Society, 11(3), 197-211. http://dx.doi.org/10.5172/rsj.11.3.197

Martinez, S., \& Kaufman, P. (2008). Twenty years of competition reshape the food marketing system. Amber Waves, Washington DC, US. http://purl.umn.edu/123216http://purl.umn.edu/123216

McEachern, M., \& Willock, J. (2004). Producers and consumers of organic meat: A focus on attitudes and motivations, British Food Journal, 106(7), 534-552. http://dx.doi.org/10.1108/00070700410545737

Newspoll, (2008). Organic Food. Sydney, Australia: Organic Federation of Australia.

Organic Federation of Australia. (2014). National organic mark. Organic Federation of Australia http://www.ofa.org.au/national_organic_mark

Organic market $\quad$ report $2013 . \quad$ Soil Association, Bristol, http://www.soilassociation.org/LinkClick.aspx?fileticket=whbpEnZUd7A\%3d\&tabid=1984

Organic Traders Association. (2011). Industry statistics and projected growth. Organic Trade Association, Vermont, USA. http://www.ota.com/organic/mt/business.html 
Organic Traders Association. (2013). U.S. Families' Organic Attitudes and Beliefs Study. Organic Trade Association, Vermont, USA.

Padilla, B., Cordts, A., Schulze, B., \& Spiller, A. (2013). Assessing determinants of organic food consumption using data from the German National Nutrition Survey II. Food Quality and Preference, 28(1), 60-70. http://dx.doi.org/10.1016/j.foodqual.2012.08.010

Pearson, D., \& Henryks, J. (2008). Marketing Organic Products: Exploring Some of the Pervasive Issues. Journal of Food Products Marketing, 14(4), 95-108. http://dx.doi.org/10.1080/10454440801986421

Pearson, D., Henryks, J., \& Jones, H. (2011). Organic Food: What we know (and don't know) about consumers. Renewable Agriculture and Food Systems, 26(2), 171-177. http://dx.doi.org/10.1017/S1742170510000499

Pearson, D., Henryks, J., \& Moffitt, L. (2007). What Do Buyers Really Want When They Purchase Organic Foods? An investigation using product attributes. Journal of Organic Systems, 2(1), 1-9.

Pearson, D., Henryks, J., Sultan, P., \& Anisimova, T. (2013). Organic food consumers: Exploring purchase frequency to explain consumer behaviour. Journal of Organic Systems, 8(2), 50-63Soil Association.

Sawyer, E., Kerr, W., \& Hobbs, J. (2008). International marketing of organic foods: consumers, standards, and harmonization. Journal of International Food \& Agribusiness Marketing, 21(1), 44-66. http://dx.doi.org/10.1080/08974430802480644

Sax, L., Gilmartin, S., \& Bryant, A. (2003). Assessing response rates and nonresponse bias in web and paper surveys. Research in Higher Education, 44(4), 409-432. http://dx.doi.org/10.1023/A:1024232915870

Shepherd, R., Magnusson, M., \& Sjödén, P. (2005). Determinants of consumer behaviour related to organic foods. Ambio, 34(4-5), 352-359. http://dx.doi.org/10.1579/0044-7447-34.4.352

Smed, S., \& Andersen, L. (2012). Information or Prices, Which Is Most Powerful in Increasing Consumer Demand for Organic Vegetables? International Business Research, 5(12), 175-194. http://dx.doi.org/10.5539/ibr.v5n12p175

Thøgersen, J. (2010). Country differences in sustainable consumption: The case of organic food, Journal of Macromarketing, 30(2), 171-185. http://dx.doi.org/10.1177/0276146710361926

Thompson, G., \& Kidwell, J. (1998). Explaining the choice of organic produce: Cosmetic defects, prices, and consumer preferences. American Journal of Agricultural Economics, 80(2), 277-287. http://dx.doi.org/10.2307/1244500

Wansink, B. (2003). How do front and back package labels influence beliefs about health claims? Journal of Consumer Affairs, 37(2), 305-316. http://dx.doi.org/10.1111/j.1745-6606.2003.tb00455.x

Willer, H., Lernoud, J., Kilcher, L. (eds). (2013). The world of organic agriculture: statistics and emerging trends. 14 ed. Bonn, Germany, International Federation of Organic Agriculture Movements (IFOAM); Frick, Switzerland, Research Institute of Organic Agriculture (FiBL).

Wright, K. (2005). Researching Internet-based populations: Advantages and disadvantages of online survey research, online questionnaire authoring software packages, and web survey services. Journal of Computer-Mediated Communication, 10(3), 11. http://dx.doi.org/10.1111/j.1083-6101.2005.tb00259.x

Yin, S., Wu, L., Du, L., Chen, M. (2010). Consumers' purchase intention of organic food in China. Journal of the Science of Food and Agriculture, 90(8), 1361-1367. http://dx.doi.org/10.1002/jsfa.3936

\section{(c) $)$ EY}

This work is licensed under a Creative Commons Attribution 3.0 License. 